\title{
連載記 事
}

\section{「インターナショナル・フォーラム」 \\ （第十五回） \\ 新たな農業機械を求めて世界と繫がる}

岸田 義典

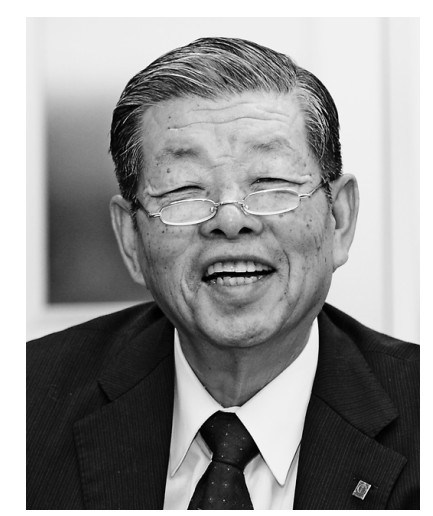

株式会社新農林社・代表取締役社長

筆者が現在社長を務める株式会社新農林社は, 先代岸田義邦が昭和 8 年（1933 年） 2 月に株式会 社中外農林新聞社として発足し農業機械の専門新聞 出版社として活動を始めた. 戦時統制経済の中で, 政府の要請により農業関倸新聞雑誌社 6 社を吸収合 併し昭和 18 年に株式会社新農林社と社名を新たに した. 先代が昭和 8 年から 40 年間社長をし, 筆者は 31 歳で社長になり現在まで約 42 年間社長を務めて いる. 我々の主要なキーワードは農業機械及び農業 機械関連工学であり研究, 開発, 教育等の大学, 学 会活動ばかりでなく, 実際の農業機械化を進めていく 農業機械産業と深い関わりを持って日本ばかりでなく 世界の農業機械化を推進してきた。

筆者は早稲田大学理工学部機械工学科を卒業し た後, 現在の三菱マヒンドラ農機株式会社（元佐藤 造機株式会社）の研究部に入り高水分稲を脱款でき る新しい脱穀機の研究開発に携わった. 籾とチヤフを 選別するために摇動選別システムなどのアイデアを出 し, それらは新しい選別の基礎パテントとなり現在日本 だけでなく中国や台湾, 韓国その他アジア地域などで
も広く使われている自脱型コンバインの選別部として活 躍している. 大学時代に筆者は佐藤常三先生の産業 数学のゼミで学び, 全ての物理量は統計量であるとい う教えのもとに工学的諸問題を統計的数学的に考え ていくという方法論を学んだ.これは農業機械の研究 開発に非常に役に立つことになった. 例えば脱穀する 時の稲の物理性などは稲の品種や刈り取りの時期や 地域によっても大きく異なり統計的な手法で材料把握 をしなければならないからである。

1966 年の 3 月に初めて先代に連れられヨーロッパと 米国の農業機械事情の視察を行った. ヨーロッパでは Verona で行われた大規模な農業機械の展示会を視 察し,ドイツの München 工科大学に Söhne 先生を 訪問し, また Braunschweig の農業工学研究所では 最新の研究を見せていただいた. 特に印象に残って いるのはジャガイモと石の選別に関する色々な手法を 用いた研究であった. それらの研究結果は現在実際 の農業機械, ジャガイモの収穫機の選別方法として製 品化され広く農家に使用されている. ドイツの大学や 
研究所で行われている研究は何年かすると必ず実際 の新しい農業機械製品となって世に出てくることに非 常に大きな感銘を受けた．英国の Silsoe では国立農 業工学研究所を訪問し, 農業機械のテスト方法や 様々な分野の新しい工学研究に目を開かれた.アメリ カでは先代が昭和 33 年（1958 年）に米国政府に 招かれ日本の農業の生産性を高める目的で農業機械 化の勉強をした時にベースキャンプとなった North Carolina 州の Raleigh にある NC 州立大学をまず訪 問した. 当大学にはその後 1967 年 1970 年と訪問し 様々な分野の新しい研究を見ることが出来た，その時 非常に興味を引いたのがたばこの生育を圃場で均一 化するための研究であった. 環境制御箱を使い光の 波長や強度, 当てる夕イミングや時間, さらに炭酸ガス 濃度, 肥料の種類や濃度などなど, 植物成長に影響 を与える様々な要因を変えて, たばこの成長モデルを 作ろうとしていた. NC 州立大学では世界の他の大学 に先駆けて学科名を Department of Agriculture and Biological Engineering としていた. 施設園芸の将来 にとり大変重要な研究だと思い, 帰国後農林水産省 や経済産業省に出かけそのような研究を推進すること を提案した．そして当時のお金で約 100 万円を $\mathrm{NC}$ 州立大学の先生に支払い環境制御に関する調査研 究を行い日本の某メーカーに環境制御箱の研究開発 と製品化を提案した. その時, 確か Johnson 先生と お名前を記憶しておりましたが, たばこの乾燥の自動 化を行うためにたばこの葉の葉緑素を近赤外線で測 って制御するという研究を始めていた。一緒に行って いたのは McClure 先生であり, 先生はその後近赤外 線を使って様々な物質の測定をすることになり第一人 者となった. それらの研究成果は大豆のタンパク質の 計測器につながり正味のタンパク含有量によって大豆 の取引価格が決まるということも実現された. 1970 年 当時のことであるからすでに 45 年前のことである. ま たBowen 先生は土のモデル化をしていたし，

Rohrback 先生は近赤外線を使ってブルーベリーの選 別機を研究していた. 日本でもその後橋本先生や高 倉先生など植物と環境の関わりについての様々な研究 を行ったが, 欧米は新しい研究への着手が非常に早 いと感銘をした.

その後, Iowa 州立大学, Ohio 州立大学,
Michigan 州立大学, Alabama 州の Auburn にあっ た国立耕耘機械研究所, Carifornia 大学, Hawai 大 学等を訪問したが, それぞれの地域に合った新しい 意欲的な研究がなされることに非常に勉強をさせられ た.

さて, 日本では生物環境調節学会と植物工場学会 が合体して日本生物環境工学会が設立された. 研究 内容を見ると主として植物と環境に関する研究が大部 分を占めている. CIGR 等の研究部会活動を見ると植 物ばかりでなく畜産の盛んな欧米では動物の環境に 関する研究が非常に重要である. 動物の環境に関連 する研究は農業施設学会などでも行われているが日 本生物環境工学会などにも動物を含んだ環境制御の 研究部会が必要であると思う. 特に人間はこの地球 上で全ての生命系と調和をして生きていかなければな らない. 宇宙空間例えば月面などに長期的に人間が 生活していく施設を考えた場合でもその中に生存する 人間, 植物, 動物, 微生物等のシステムの研究とトー タルな環境制御の研究が非常に重要となる. 最近は 植物と微生物の間の情報のやり取りなどの研究も進ん できている.あらゆる生物を含んだシステムの環境制 御に関する研究はこれからの人類に取り非常に重要 である。

1970 年に私は一人でヨーロッパに 35 日間アメリカに 105 日間行き, 多くの研究機関や有名農業機械メーカ 一等を訪問し勉強した. その時の目的の一つはどうし たら日本の農業は欧米の農業に労働生産性で勝てる かという問題の解決案を見つけることであった。

欧米を訪問しての私の結論は, 日本は構造改善事 業を巨額のお金を長年かけて行っているが 100 年し ても欧米のような大きな作業区画は作ることができない ということである.すると日本は欧米に比べて小区画で 多数分散戋場を使って労働生産性を上げられる新し い生産機械化システムの研究開発をしなければならな いということであった。 その当時農業の機械化は人間 の頭脳の機械化ではなく主として人間の筋肉力の拡 大であった．固場効率などもあるが 100 馬力のトラク夕 の代わりに 200 馬力のものを使えばほぼ倍の生産性 があげられるのである. しかし日本では大型の機械を 使うには限界がある. そこで筆者が考えたことはオぺ 
レーターの頭脳を徹底的に機械化すればいいのでは ないかということである. 欧米の農家が将来 1000 馬 力のトラク夕を使うようになる時に日本は徹底的に知能 化された 20 馬力の機械をいっぺんに 50 台使えるよう にすればよいのである. 当時の色々な工業製品を調べ てみると 1000 馬力の機械を一台作るより 20 馬力の 機械を 50 台作った方が安くなるケースがあった. また 頭脳の機械化コストを下げるためにはそれぞれに持た せる頭脳機能は下げて中央で皆が使えるコンピュー夕 に高度の機能を持たせて, 最終的には人間と結び, そのような情報ネットワークシステムを研究開発しなけ ればならないと思った。

1970 年夏に帰国してそのようなアイデアを農林水産 省の技術会議等に持っていって農業ロボットの研究開 発を推進してほしいと言ったが当時筆者は 28 歳でな かなか相手にしてもらえなかった. また大学の先生方 には個々の機械と大きな中央コンピュータと人間の情 報処理ネットワークシステムの研究してほしいと言った がこれもなかなかやってもらえなかった. 最近やっとそ のような事を実現していく様々な要素技術が開発され てきたので近い将来筆者の夢は叶うものと信じている.

構造改善に年 3000 億円も使うならばその 1 割か 2 割のお金を投入すれば 10 年もすれば新しい自動小 型機械システムが開発されると信じている. そうすれ ば毎年構造改善に巨額の予算を投入しなくて済むの であるから国家経済にとっても有益である.

ジャーナリストとして新聞出版活動に従事してきた が, 大きな楽しみは全国の色々なメーカーに行って研 究部の人達と研究開発の話をしたり大学訪問して新し いものを見せてもらったり将来の夢について話し合うこ とだった. 小型農業ロボットの挑戦については 30 数年 前にヨーロッパの Simon Blackmore 先生に話をしたこ とがある. 現在先生はヨーロッパにおける小型農業口 ボットの研究のオーソリテイとなっている.

国内ばかりでなく毎年のように色々な国を訪問し多く の農業機械工学に関連する先生方, メーカーの方々 と会うことが多く, 色々な形で勉強させてもらったことが 非常にありがたいと思っている. 先代は農機産業の発 展のために最も必要なことは新しい農業機械の研究
開発であるという信念のもとに農業機械学会の活動を 色々な形での助言・援助してきた. 先代の時代に我 が社で農業機械学会の事務局を 10 年以上引き受け 我が社の営業を使って広告を集め学会の運営や財政 の健全化に尽力した. その後京都大学の川村先生が 会長になったとき再び財政難に陥り筆者は再び新農 林社で 3 年間事務局を引き受け, 私も事務局長として 財政再建のために働いた. 3 年間で財政危機を克服 し事務局を農業機械学会に戻しその後は今の生研セ ンターで事務局が続いている.

日本の学会活動ばかりでなく海外の進んだ研究開 発を見るには海外の学会に加入し積極的に年次大会 等に参加し新しい研究開発に触れようと努力した。 そ の結果先代もアメリカの ASABE（American Society of Agricultural and Biological Engineers, 元 ASAE) の会員に日本人として初めてなった. 私もその後先代 が亡くなった後会員となり今年長年の会員活動の功績 に対して Fellowをいただくとが出来た. ASAEに依 頼されて 1978 年に学会員の国際活動を奨励するた めに岸田国際賞（Kishida International Award）を 設立した，それは現在でも続いており ASABE のいろ いろな Award の中でも古株になりつつある.これらの 賞が世界の農業のために役に立てばと思っている.

世界農業工学会（CIGR）については山中勇先生 がその重要性に気付き日本の研究者を参加させるた めに世界農業工学会の日本支部を作り学会誌を発行 した. しかし財政的に難しい点があり筆者は相談を受 けて農業工学に関連する各学会の連合会をしっかり させ，そこを通して CIGRに参加するのが良いと提言 した. 各学会の会誌を活用すれば良いと提案しさらに 事務局を引き受けてもらうために最大の学会, 農業土 木学会を訪問し了承を取り付けたのも懐かしい思い出 である. CIGRの本部には理事として参加をすることに なり大学の教授でもないのに日本から私一人が本部の 理事として活動させて頂いた. CIGR からもアジアで初 めての Fellow を頂いたのもありがたい思い出である. その後 3 回ほど CIGR の財政が難しい時に初めて二 ュースレターに広告を集めて財政再建に寄与すること も出来た. 
また思い出深いことは 1980 年代の終わりにタイにあ る Asian Institute of Technology (AIT) の農 業工学 部長をしていた Gajendra Singh 先生達とアジア地域 の学会 AAAE（アジア農業工学会）を立ち上げたこ とである. 筆者も学会長を一度務めた.アジアは世界 最大の人口を持つ地域であり農業の発展は地球上で 最重要の地域である, 農業の発展には地域に合った 農業機械化や農業工学がもつとも重要であり, それに は長期的地域の協力体制の構築が重要である. AAAE の役割は今後更に重要である. CIGRの最重 要地域学会となりつつあり, 日本の農業工学関係者の 積極的参加が不可欠である.

さらに，筆者は 1971 年 4 月に「AMA, Agricultural Mechanization in South East Asia」と いう英文の雑誌をスタートさせた. その当時世界の人 口の約 $80 \%$ が開発途上国の農民であり大変貧しい 生活を強いられていた，世界的に都市の住民との経 済格差が拡大していた. 狭くなる地球の中で経済格 差の拡大を放置しておけば決して平和な世界にはな れないと思い, どうしたらよいか考えた末，それぞれの 農家が適切な道具, 技術を使って自分の立場を改良 していくことであると思った，そのための道具を皆で研 究しなければならないと思い, 開発途上国の専門家と 先進国の専門家を横につなぐ雑誌を考えたのである. 先代に相談すると, 農機新聞や機械化農業に十分な 広告もとれないくせに, 創刊してもつぶしてしまうから 新農林社の名前を使っては䭾目だと言われた. どうし てもやりたかったので子会社である株式会社農機産 業調査研究所の名前で先代の了承を得て発刊した. 1 万部発刊し世界の農業機械関連機関に送付したこ ところ, 反応があり特に南アジアの国から我々も入れて くれという要望があり2号目からは夕イトルを「AMA, Agricultural Mechanization in Asia」とした. 1981 年にオランダの Wageningen 大学の Moens 教授が夕 イトルを変えた方が良い，世界で読まれているのたからら アジアの農業機械化というタイトルはおかしいと述べら れた. しかし AMAは 10 年の間に名前を覚えられた ので, AMA の最後の Aを3つの Aという意味にして 新しい夕イトルを「AMA, Agricultural Mechanization in Asia, Africa and Latin America」とし, 現在に至っ
ている.

昨年嬉しかったことはインド農業工学会の年次大会 に行った時に大学の先生から The National Academy of Agricultural Sciences(NAAS) という機 関が農業工学に関する学術誌の評価を行っているが AMA がトップにランキングされスコアが 6.06 だという. 第 2 位は ICAR Journal(インド農業研究評議会誌) で 6.0 , 第 3 位はインド農業工学会が発刊する学会誌 (ISAE Journal) で 4.85, 4 位はアジア農業工学会の 学会誌（AAAE Journal）2.85 でありあなたの雑誌が トップだと言うのである. 1971 年から考えると 44 年近く 時間が経ちその間にそのような高評価を頂ける雑誌に することが出来たということは出版を企画し推進してき た者としてはたいへん嬉しかったことである.

人口がまだ増える中で持続的に農業を行うには様々 な制約条件があり, 人口一人あたりの農地も水も減少 する. そのような中で気候の温暖化等で気象条件も厳 しくなってきている. 結局土地生産性を向上させる技 術, 新しい栽培機械化システムを普及させなければな らない. 農業機械は土地生産性を上げるために必要

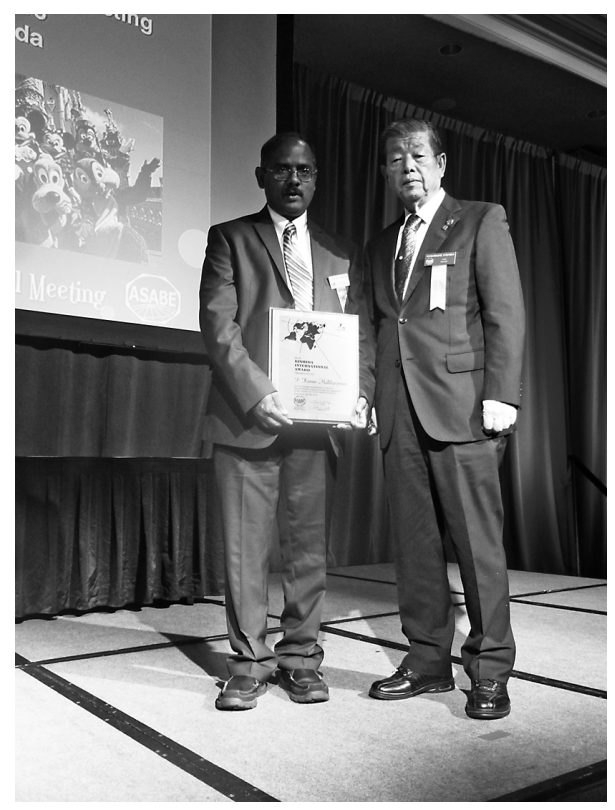

2015 年 7 月ニューオリンズでの ASABE 会議で岸 田国際賞を受けた P. Kumar Mallikarjunan 氏と 筆者 
不可欠な適期作業と正確な作業を行うためにも不可 欠である. 農業機械化が今後の食料問題を解決する といっても過言ではない.

しかし日本では重要性を増してくるキーワード「農 業機械」が大学から見えなくなってしまったことが残 念である. 農業機械学会も名前を変えてしまった. 人 工知能の利用と共に農業機械も新たな頭脳化された 農業機械ロボットとしてこれからの新しい農業を作って いくものと筆者は信じている. また様々なデータがネット でつながり人類史上例を見ない巨大な情報処理シス テムが出来ようとしている. これらを世界の人々の幸せ のために良い形で皆で活かしていかなければならない と思う. 最近の若い人は留学をしたがらない, 出張を したがらないと言われ何か閉じこもりがちなように見え るが, 空間的な移動をしなくても既に我々は世界とつな がらなければならない状況が今まで以上に起きている のである. 世界と密接につながる中でイニシアチブをと
り創造的な新しい研究, 仕事をしていく多くの若い研 究者が日本の中で活性化し世界で活躍することを筆 者は心から願うものである.

このような巨大な情報システム社会の中で結局全て は人が行うのであり, 人とのつながりが重要である. 学 会活動は今まで以上に重要になると思う. 若い人の積 極的な世界諸学会への参加活動を期待している.

人間は地球上の生物システムの一員であり持続的 生存の為には生物システムとの調和が必要であり, そ の調和作業が広義の農業である. その作業の科学が 広義の農業工学である. 調和作業の結果として生命 系からは食料, 森林と林産物, 薬品, 繊維, 豊かな 環境, それに加え生命系に働きかけることにより人間 が獲得するソフトウェア, 精神や心があり, それらが文 化文明を歴史的に形成して人類を変えてきたのであ る. 農業工学は人類にとり現在最重要である. 